\title{
Ulysses: The Novel, the Author and the Translators
}

\author{
Qing Wang \\ Shandong Jiaotong University, Jinan, China \\ Email: wangqing6906@126.com
}

\begin{abstract}
A novel of kaleidoscopic styles, Ulysses best displays James Joyce's creativity as a renowned modernist novelist. Joyce maneuvers freely the English language to express a deep hatred for religious hypocrisy and colonizing oppressions as well as a well-masked patriotism for his motherland. In this aspect Joyce shares some similarity with his Chinese translator Xiao Qian, also a prolific writer.
\end{abstract}

Index Terms - style, translation, Ulysses, James Joyce, Xiao Qian

\section{INTRODUCTION}

James Joyce (1882-1941) is regarded as one of the most innovative novelists of the 20th century. For people who are interested in modernist novels, Ulysses is an enormous aesthetic achievement. Attridge (1990, p.1) asserts that the impact of Joyce's literary revolution was such that "far more people read Joyce than are aware of it", and that few later novelists "have escaped its aftershock, even when they attempt to avoid Joycean paradigms and procedures." Gillespie and Gillespie (2000, p.1) also agree that Ulysses is "a work of art rivaled by few authors in this or any century." Ezra Pound was one of the first to recognize the gift in Joyce. He was convinced of the greatness of Ulysses no sooner than having just read the manuscript for the first part of the novel in 1917. T. S. Eliot praised Joyce as "the greatest master of the English language since Milton" (Jin, 2001, p. 225).

\section{JAMES JOYCE: THE MODERNIST NOVELIST}

James Joyce was born in Dublin, Ireland, on February 2, 1882, the eldest of 10 children of John and Mary Joyce. Owing to the fast diminishing prosperity, he had to withdraw in 1891 from Clongowes Wood College, an elite Jesuit school, where he had studied earnestly for three years. He enrolled as a day student at Belvedere College, another Jesuit school, in 1893, where he showed great talent in writing and won academic prizes, including the prize for the best English composition in Ireland in his grade. In 1898 Joyce entered University College, Dublin, and graduated with a degree in modern languages (English, French and Italian) in 1902. Following university, Joyce left Dublin for Paris, ostensibly to study medicine, but came back the following year on receiving news of his mother's fatal illness. He had apparently abandoned medicine and started writing for magazines later to be included in his Chamber Music (1907), a collection of poems, and Dubliners (1914), a collection of short stories. On 10 June, 1904 Joyce met Nora Barnacle, and their first outing took place on 16 June the same year when they walked to the Dublin village of Ringsend, a date that later became celebrated as "Bloomsday" as a commemoration observed annually in Dublin and elsewhere to celebrate the life of Joyce and relive the events in his novel Ulysses.

To support his family, Joyce gave English lessons at the Berlitz School, first in Pola, Yugoslavia, and later in Trieste, Italy, and also worked in a bank in Rome copying out letters, but all the while he kept working on his stories and novels. With the help of Ezra Pound, his A Portrait of the Artist as a Young Man, which he, since 1907, had started rewriting from Stephen Hero, an unfinished draft of an autobiographical novel, appeared in serial form in the Egoist in 1914, and was finally published in New York in 1916. In 1914 Joyce began working on Ulysses, which was first serialized in Little Review, and finally published in Paris in 1922 by Sylvia Beaches' bookshop, Shakespeare and Company, and in 1934 by Random House in New York. He began working on Finnegans Wake in 1923. This novel, which was to be Joyce's last, was published by Faber \& Faber in London and Viking in New York in 1939. Joyce suffered from a perforated ulcer and died on 13 January, 1941.

Joyce's status as a modernist writer is well-established in English literature. Broadly speaking, the modernist writers in English literature occupied the first 40 years of the twentieth century (Miller, 2006, p.1). Like other modernist novelists and poets such as Conrad, Forster, Lawrence, Elliot and Woolf, Joyce was also influenced by Sigmund Freud, whose psychological theories that human behavior is influenced more by subconscious drives than by reason and logic inspired the modernists to turn to the inner life of the character as the focus of art. The modernist artists found interiority a good form to explore the theme of the alienated individual in the radically, disastrously altered world during and after the First World War. Encouraged by Ezra Pound's catchphrase "Make it new," these artists were strongly aware of the need to find or create a new language, a new style, to articulate the reality of experience in the modern world. Joyce's A Portrait of the Artist as a Young Man (1916), Ulysses (1922), and Finnegans Wake (1939) are three 
novels that manifest ever more radical stylistic experimentalism.

With A Portrait, Joyce began to forge a narrative style that mapped the development of the mind and abilities of the growing artist Stephen Dedalus, literally from infancy to adulthood. The fragmented and simple style that opens the novel: "Once upon a time and a very good time it was there was a moocow coming down the road" is reflective of a child's mental state in understanding the world. The subsequent four chapters progress to more complex logic and subtle perception of a sensitive and artistic young man. This novel is regarded as Joyce's "nascent experimentalism" (Miller, 2006, p. 83). It is composed in a stream-of-consciousness style, which is further complicated by Joyce's employing techniques of free indirect speech, which as Semino and Short note, is "ambiguous with respect to the 'words and structures' faithfulness claims" (Semino and Short, 2004, p. 13).

These modernist techniques of experimentalism grow into maturity in Ulysses. The episodic development shifts from the protracted chronicle of growth from infancy to adulthood in A Portrait to the compact 20 hours or so - from 8 a.m. June 16, 1904 to 4 or $5 \mathrm{a} . \mathrm{m}$. the following day. Still focusing on exploring the nuances of a character's inner life, Joyce experiments with more writing techniques: stream of consciousness, free indirect speech as well as interior monologue are used frequently and masterfully. Ulysses is especially noted for its vagaries of style, as explained by Butler, "by the time he is writing Ulysses he has set himself the 'task' 'of writing a book from eighteen different points of view and in as many styles, all apparently unknown or undiscovered by my fellow tradesmen'." Butler further points out that by disrupting the conventions of word formation and syntax, Joyce begins his "revolution of the word" (Butler, 1990, p. 261), which is complete in Finnegans Wake.

Joyce's final work, Finnegans Wake, is often cited as the logical end of the line of his radical experiment with language and style. This novel is clearly indebted to Freudian psychoanalysis, as Butler argues, "A Freudian interpretation of its language, and a Jungian one of its myths and symbols, seem inevitable." (ibid, p. 273) Joyce experiments more radically with the English language and style, making it the most esoteric of the novels ever written. It is so difficult to read that even Ezra Pound wrote to Joyce, complaining that "nothing so far as I make out, nothing short of divine vision or a new cure for the clap can possibly be worth all the circumambient peripherization" (16 November 1926; Letters III 145, in Norris, 1990, p. 173). Norris assures us that no other existing literary work needs a "guide" more sorely than Joyce's Finnegans Wake, "with its strange language, its neologisms, its generic ambiguity, the obscurity of its allusions, the mysterious status of its speech." Even with a guide all along, the common reader often feels baffled to make sense of the words, such as

[1] Behailed His Gross the Ondt, prostrandvorous upon his dhrone, in his Papylonian babooshkees, smolking a spatial brunt of Hosana cigals,... as appi as a oneysucker or a baskerboy on the Libido, with Floh biting his leg thigh and Luse lugging his luff leg and Bieni bussing him under his bonnet and Vespatilla blowing cosy fond tutties up the allabroad length of the large of his smalls.

If the novel is unintelligible even to the native reader, it is even more so to foreigners. When Joyce's linguistic experimentalism in Finnegans Wake results in incomprehensibility of the text, the novel seems to bring only bewilderment rather than pleasure to the common reader. It is in this sense that Xiao Qian, who has translated Joyce's Ulysses, remarked when talking about Western Modernism literature that Joyce has wasted his gift upon taking the road of an impasse (Xiao Qian, 2005a, p. 4).

\section{ULYSSES: STRUCTURE AND STYLE}

Ulysses is regarded the best of the three novels Joyce has written. In Ulysses, Joyce displays to advantage his masterful ability to compose a simple story elaborately, to exploit the English language creatively, and to express his deep concern for his Irish motherland through mask and mockery, making the novel a nationalistic epic in prose. One of the major claims to importance which Ulysses has in the canon of twentieth-century literature is that it may well be the first novel fully realize the vision of Flaubert, that the novel should evolve toward a "novel of pure style", that "from the standpoint of pure Art one might almost establish the axiom that there is no such thing as subject, style in itself being an absolute manner of seeing things." (qtd. in Ellman and Feidelson, 1965, p. 126)

More than any other novel except Finnegans Wake, Ulysses asks to be reread and requires guides, compendia, maps, and a great deal of patience. As demanding as this reading process may be, Joyce believed that it is well worth it: "I don't think that the difficulties in reading it are so insurmountable. Certainly any intelligent reader can read and understand it, if he returns to the text again and again. He is setting out on an adventure with words." (Bulson, 2008, p. 71-72).

Ulysses is a parallel parody to Homer's Greek epic The Odyssey. In writing the novel Joyce referred to each of the 18 episodes by a Homeric title. These parallels allowed him to organize each episode around a single idea, theme, symbol, and narrative technique. Though Joyce removed these titles before publication, Joycean researchers still use them for convenience references. The following are the Homeric titles in Ulysses:

I. 1. Telemachus

2. Nestor

3. Proteus

II. 4. Calypso

5. Lotus Eaters 
6. Hades

7. Aeolus

8. Lestrygonians

9. Scylla and Charybdis

10. Wandering Rocks

11. Sirens

12. Cyclops

13. Nausicaa

14. Oxen of the Sun

15. Circe

III.16. Eumaeus

17. Ithaca

18. Penelope

The first 3 are grouped as "the Telemachiad", which focuses on the young poet Stephen Dedalus, who is alluded to Telemachus, the son of Odysseus. The 12 middle episodes are "the Odyssey", displaced in time and space to the streets of Dublin at the beginning of the 20th century, June 16, 1904. In this part Leopold Bloom acts as a main character, who, parallel to be Odysseus, the Homeric hero, wanders here and there through Dublin, attending his daily duties, and suffering from family unhappiness as well as public exclusion because he is a Jew. The last 3 episodes of the Ulysses epic are grouped as "the Nostos", or "Return", in which Molly Bloom, alluded to as Penelope, Odysseus's wife, is given one whole episode to speak her soliloquy. Molly weighs in her mind the three men who are associated with her life-her husband Leopold Bloom, her concert manager Blazes Boylan, with whom she begins having an affair, and Stephen Dedalus, the young poet.

Stylistically speaking, Ulysses is the most creative work of fiction of its age, regarded by critics as the kaleidoscope of style. A vigorous read, Ulysses is a feast for eclectic readers: it includes various literary forms from a parody of medieval romance to the 17th century scientific discourse in English language. With the wandering of the protagonists, the story changes scenes, and the styles change accordingly. "The Telemachiad" takes on the style of the young: rigid and somewhat awkward, as if Stephen, as a novice poet, were beginning to learn to write. The narrative techniques in the first 3 episodes are, therefore, comparatively traditional. The third-person narrator as in the beginning sentence of the whole novel

[2] Stately, plump Buck Mulligan came from the stairhead, bearing a bowl of lather on which a mirror and a razor lay crossed. $(U 1.1-2)$

promises a story with a plot, as Lawrence (1981, p. 38) points out.

From "Calypso" to "Circe", however, the writing style matures into that of an adult: experienced and flexible. Third-person narrations gradually give way to free indirect speeches and interior monologues, disclosing more of the characters' innermost thoughts than their outward appearances. What is more remarkable in these 12 episodes is Joyce's capability to accommodate style to situation. Take Episode 7 "Aeolus" for an example. The scenario in this episode is the newspaper office, where Bloom attempts to place an advertisement and Stephen arrives to see about publishing an article. The episode is broken up into short sections by newspaper-style headlines, and is characterized by a deliberate abundance of rhetorical devices. By employing such a writing style, Joyce mocks the high-sounding but vacuous Irish journalistic circle.

The last three episodes, "the Nostos", especially Episode 16 "Eumaeus", are written in a style of the elderly: sluggish, repetitive and full of clichés. By this time, the long day of June 16, 1904 has come to an end, and at such a moment of midnight all the people-Bloom, Stephen, the drunken sailor and others at the cabman's shelter, as well as Molly, who is already in bed and half-asleep - are feeling lethargic, and so is the style of the language. Suffice it to cite the beginning sentence of a paragraph in episode 16 as an illustration of verbosity and as a contrast to [2], the beginning sentence of "Telemachus".

[3] On the other hand what incensed him more inwardly was the blatant jokes of the cabmen and so on who passed it all off as a jest, laughing immoderately, pretending to understand everything, the why and the wherefore, and in reality not knowing their own minds, it being a case for the two parties themselves unless it ensued that the legitimate husband happened to be a party to it owing to some anonymous letter from the usual boy Jones, who happened to come across them at the crucial moment in a loving position locked in one another's arms, drawing attention to their illicit proceedings and leading up to a domestic rumpus and the erring fair one begging forgiveness of her lord and master upon her knees and promising to sever the connection and not receive his visits any more if only the aggrieved husband would overlook the matter and let bygones be bygones with tears in her eyes though possibly with her tongue in her fair cheek at the same time, as quite possibly there were several others. ( $U$ 16.1529-1542)

Apart from the general features of the three style chunks, Joyce also creates in the novel many subtle lexical and syntactic styles, by resorting to devices such as incomplete spellings, ungrammatical speeches, numerous wordplays as well as non-punctuated page-long sentences. Detailed analysis of such stylistic features will be conducted in chapters 4 through 7.

According to functional stylistics, style is a prominent feature in a text that is related to the intention of the language 
user, or in Halliday's words, a literary style is the author's "motivated prominence" (Halliday 1973). The intentionality of the language user in choosing a specific linguistic expression is not to be ignored in the study of style. If Ulysses were a novel that merely borrows its structure from a Greek epic and characterizes its style by kaleidoscopic changes but lacks a serious literary theme or motif as its substance, it could never have been read and appreciated by so many readers and scholars. In this most innovative and stylistically eclectic novel of its period, Joyce expresses his unremitting love and hatred. It is one of "revenge" on England's century-long intrusion into Irish political and cultural nationalism. As Gibson convincingly argues (Gibson, 2002, p. 13):

[I]n Ulysses, Joyce works towards a liberation from the colonial power and its culture. He also takes his revenge on them. There is a will to freedom in Ulysses, and a will to justice, but also a recognition that the two do not necessarily coincide.

Joyce's pervasive hostility towards England is manifested in his description of the English as a "reptile people" and English literature as "pompous and hypocritical". Joyce claims, "It is my revolt against the English conventions, literary and otherwise, that is the main source of my talent. I don't write in English." (ibid, p. 4) Indeed, when the readers of Ulysses encounter so many un-English sentences in the novel, like

[4] Yes, bronze from anear, by gold from afar, heard steel from anear, hoofs ring from afar, and heard steelhoofs ringhoof ringsteel. (U 11.112-113)

they would agree with what John Eglinton wrote in Irish Literary Portraits, that the English language "found itself constrained by its new master to perform tasks to which it was unaccustomed in the service of pure literature... Joyce rejoiced darkly in causing the language of Milton and Wordsworth to utter all but unimaginable filth and treason." (Gibson, 2002, p. 1) By abusing the conventional rules of the English language, Joyce intends to subvert the English government, as a reaction to the "Irish Ireland Movement". Although in the novel he mocks bitterly the stupidity and paralysis of Dubliners, for which he incurred so fierce hatred from his countrymen that he never returned to Ireland but chose to die in exile, his concern for his motherland is deeply hidden and can be felt in this nationalistic epic of Ulysses.

\section{TRANSLATION OF ULYSSES IN CHINA}

Joyce lived to see this masterpiece of his in other languages, but he showed so great concern for the quality of the translations that he even took all the trouble to visit the Danish translator, only to tell her "not to change anything in the novel, not even a word". This would be utterly impossible. What he demanded of his translators, actually, was a conscientious attitude and adequate attention to the peculiar features that characterize Ulysses, making it a work distinctive from any other novels.

The earliest translations of Ulysses were the German version (1927) and the French version (1929), and the author actually helped make final decisions in the translating process of the two versions. Maintaining regular correspondence with his German translator, Georg Goyert, Joyce explained certain esoteric points and offered his own suggestions where necessary. Upon the completion of the task, Goyert came from Munich to Zurich to see Joyce and the author edited the first 88 pages of the German translation. Even with his own assistance in the whole process, Joyce was still not very satisfied with the Goyert version. He then spent a lot of energy on the French version of Ulysses. Having studied in Paris and well-versed in French himself, Joyce organized a translation team of three professionals Valery Larbaud, Auguste Morel, and Stuart Gilbert to translate Ulysses into French. In a letter to Miss Harriet Weaver, his patron and publisher, Joyce explained that he "solved" for Larbaud "a list of difficulties" which the translator had sent him, but as to the "great deal of licence" Morel had taken "here and there, sometimes incorporating whole sentences of his own manufacture", he had them all "struck out". Joyce admitted that the translation "is really his [Morel's] and has been done with great care and devotion, but like many other people, by dint of brooding on it he sees one aspect to the exclusion of another." It took seven years, 1922 to 1929, even with Joyce's personal supervision, to complete the French translation.

When the heroic Ulysses was born in the West, the Chinese readers, though far afield, heard its loud cry and gave response. In Novels Monthly, Issue 11, Vol 13, 1922, Chinese novelist Mao Dun announced the newly-born novel to his readers (Wang Yougui, 2000, p. 79-80):

James Joyce's Ulysses has recently been published...James Joyce is a quasi-Dadaist American writer. Even when Ulysses was serialized in the Little Review, some "vulgar" readers had written, burning with scorching words, to the editors of the magazine, which boasted itself of its "different tastes from the vulgarians". Meanwhile there are enthusiastic comments from young readers as well. The British youth also like Joyce, probably because of Wilss's praise on A Portrait of the Artist as a Young Man, an earlier novel of Joyce. The influential critic Arnold Bennett, however, voiced his dissatisfaction with the casually broken sentences in the novel which, in his opinion, are the very contrary to the rules of writing. Though admitting that some best parts of the writing will be immortal, his comments are more negative than positive.

Mao's brief and neutral introduction, which was erroneous in Joyce's nationality, was based on second-hand information, for he himself could not have read either of the two novels mentioned. One Chinese writer who actually read Ulysses was Xu Zhimo, a young romantic poet studying at Cambridge University at the time Ulysses got published in Paris. In the foreword to his lyric "Dusk at Cambridge" (1922) Xu expressed his admiration:

I believe this book is not only a unique work for this year, but will be so for a whole historical period. The last 100 
pages of his book (which has more than 700 pages in all) are written in a prose which is absolutely pure -- smooth as cream, and clear as the stone font in a church. It is not only free from capital letters, but is totally unburdened with all those tiresome marks like, ... ? : -- ; -- ! ( ) “". There is neither the division of paragraphs, sentences, chapters or sections. Just a flow of limpid, beautiful, torrential text pouring forward, like a huge bundle of white poplin let loose, a large waterfall coming down without any break. What great masterly art! (Jin Di's translation, 2001, p. 16)

Neither Mao nor Xu attempted to translate Ulysses for Chinese readers, though both were translators. Another translator, Wu Xinghua, took the translating task. Wu translated "A Painful Case" from Dubliners and three fragments of Ulysses and got them published on a special issue of Joyce in Western Literature in 1941.

Since the foundation of the New China when heroic revolutionary spirit was used as a yardstick of literature Ulysses became a novel of poison, full of "nihilism, philistinism and obscenity" (Jin, 2001, p. 24-25). The executive editor of the Joyce Issue of Western Literature was, in the irrational decade of "Cultural Revolution" (1966-1976), accused of poisoning the youth's mind. The translation of Ulysses, however abridged, was nipped in the frosty climate.

The Chinese reader would have to wait till the frost thawed in the spring for the transplanting of western modernist literature in their soil. The first herald was the publication of Selected Foreign Modernist Works by Academy of Social Science of China in 1981, which included the "Nestor" episode of Ulysses translated by Jin Di. Though Jin merely transplanted a rather disproportionate twig of the giant tree in the foreign soil, it would grow in favorable conditions. In subsequent years Jin translated two other episodes "Hades", "Wandering Rocks" as well as fragments from episodes "Penelope" and "Circe", and, encompassing them in Selected Translation of Ulysses, brought them out at the Hundred Flowers Literature and Art Press of Tianjin in 1986. Jin's complete Chinese translation of Ulysses was finally published by Chiu Ko Publishing Company of Taiwan, with the first 12 episodes coming out in October 1993 and the last 6 in February 1996. After negotiation of the copyright, the People's Literature Publishing House on mainland China was authorized to publish the first volume of Jin's Ulysses in April 1994, and the second in 1996.

Almost at the same time when Jin was working on his full translation of Ulysses, Xiao Qian and his wife, Wen Jieruo, also a professional translator versed both in English and Japanese, were commissioned by Yilin Press in August 1990 to translate the novel. Xiao was selected as the major translator because he was a professional translator and writer. His Chinese translation of Jonathan Wild the Great and The History of Tom Jones, a Foundling by Henry Fielding and Tales from Shakespeare by Charles and Mary Lamb were popular among Chinese readers. The short stories he wrote such as Silkworms (1933), The Captivated (1934), Chestnuts (1935) and Sunset (1937) were also appreciated and widely read in China. In 1938 Xiao wrote Dreamy Valley, the only novel of his, which gained popularity among the youth for its romantic theme and lyric diction. This translator-writer's high proficiency in the source and target languages convinced the publishing press that he would be qualified for the challenging task of translating Ulysses. The press also knew that Xiao had been studying Joyce when he was a postgraduate at Cambridge University and as early as in the 1940s Xiao expressed the idea in his postcard to $\mathrm{Hu}$ Shi, the renowned scholar, that if the novel were translated into Chinese, its writing techniques would be inspirational to the Chinese novelists. Persuaded by Mr. Li Jingduan, the head of the Yilin Press, Xiao and his wife eventually embarked on the task. Their first volume of the translation was published in April 1994, and the second volume in October of the same year.

Ulysses translated by these senior scholars won popularity among Chinese readers. One year after its publication, Xiao's Ulysses received the national prize for foreign literature, and Jin's Ulysses won the same prize in 1998, in the wake of the publication of the complete version, both awarded by the Press and Publication Bureau of the People's Republic of China. It is quite unprecedented in the bureau's history to award the top prize to different versions of the same foreign work. The prizes accredit the quality of the translational feat; the two thick masterpieces loom like "two abreast peaks, each with its unique charm.” (Lv Jun, 1995, p. 35- 40).

\section{XIAO AND JOYCE: SPIRITUAL AFFINITY OF THE TwO WRITERS}

Ulysses, the last work Xiao translated in his life, is universally acknowledged as the acme of his literary career, which manifests the summation of his achievement and artistic skills in literary translation.

Xiao attached great importance to the proper choice of work to be translated. By "proper" he means those works that are not only commonly acknowledged as valuable but agreeable to the translator's taste and disposition as well. In the 1930s while working as an editor for the literary column for Dagong Weekly, he wrote about the importance of translating works that one likes (Xiao Qian, 2005b, p. 137):

Dickens is not likely to be translated well by one who lacks a sense of humor. Nor can Conrad or O'Neill be translated lively if the translator falls short of lived experience at the sea. Likewise, a translator of Mansfield must be embodied with a soul as subtle and delicate as the authoress herself... The best way to guarantee a good translation is to choose an author you love, with whom you share similar life experiences.

Xiao himself best exemplifies the point he advocates. The similarity between the two authors of Xiao and Joyce explains the success of his translation of Ulysses. As early as 1929 Xiao heard for the first time of the name of this rebellious novelist in classroom lectures. A decade later when studying in London he began to devour Joyce's Dubliners, A Portrait of the Artist as a Young Man, and Ulysses. Hence chronologically speaking, Joyce did not exert direct influence on Xiao's story and novel writing, which were all written before he went abroad. It is an interesting coincidence that Xiao and Joyce shared quite a few similarities in their literary creations. 
Firstly, the two writers share a similar way to get source material of literary writing: personal life experiences. Xiao's writings are also mostly auto-biographical, centering on his boyhood experiences, and molding characters in his own cast. He was the knowledge-hungry boy struggling against destiny for schooling (Pear Peels), the fatherless boy suffering his palm to heavy ferule for delayed tuition fee (Low Eaves), the homeless boy who eventually learns to behave himself in other's home (Under others' Roofs), and the milk boy who swallows bitter insults and bullies (Little Jiang). However, for all these sufferings, he was still a boy-naughty, bold and chivalrous (The Captivated). The only novel Dreamy Valley is framed on the author's calf love at the age of 18, a tragedy of pure and true love crushed by an evil, wealthy and powerful rival. Xiao asserts that great works are in essence autobiographic; imagination is useful only in that it can play some role in pruning, refilling, readjusting and transforming the given source materials for a given purpose of expounding a certain aspect of life (Xiao Qian, 2005b, p. 345). In this aspect Joyce shares similar ideas. Almost all the characters in Ulysses have prototypes in Joyce's life. Stephan, the rebellious young poet in Joyce's Dubliners, A Portrait and Ulysses, is James Joyce in prototype. The voluble narrator in "Cyclops" is modeled after his father John, Molly, his wife Nora, and Mulligan, a former friend named Gogarty that Joyce believed to have betrayed him.

Secondly, religious rebellion and passionate patriotism are prominent themes in both of the authors' literary works. Four of Xiao's stories Conversion, Promising Prospect, Shen and Shang and Epiphyllum expose from varied perspectives the deceiving and enslaving attempts of missionaries and priests to convert the Chinese "infidels". Xiao's reflections on religious problems were induced by the conflicts of doctrines. In daytime at school he was taught to believe in God and to read and recite the Bible, whereas in the evening at home he was made to worship Buddhism. Life finally taught him to see through all this foolery and, waging his pen, he wrote to unveil the hypocrisy of all religions with Voltairean poignancy. Like Xiao, Joyce also articulated the pains and rebels of religion in his stories and novels. One of the themes of Joyce's Dubliners, A Portrait, and, of course, Ulysses, is the relentless revelation of the hypocrisy of Catholic Church, which accounted for the publication trouble and banning of the books. In Ulysses, Joyce wrote dozens of doggerels to mock at priests and clergymen, and adroitly reverted quotations from the Bible, for example Alleluia becomes Aiulella, and God becomes "Dooooooooooog".

Xiao and Joyce also shared common love for their motherland. Their passionate patriotism was expressed in the same fervor. In Stamps Xiao mouthed a young patriot's indignation at Japan's invasion into China through his communication with a boy who was obsessed with stamp-collecting. Patriotism was also the theme in Roadside and Chestnuts. Similarly, through the eyes and mouths and personal experiences of the minor, mediocre Irish people Joyce unpacked to the world a history of suffering from waves of foreign invaders, plunderers and manslaughters since the 10 th century. History, like a nightmare, leaves Joyce unspeakable pains, which finally found expression in one of his speech in exile: "How can a slave forget the slashes on his back?" With disintegrated portraits and deconstructive languages in all his works, Joyce "subverted the lies of colonizers, unmasked the true history, aroused the countrymen's numb conscience, and stepped further towards liberating national spirit: reflecting on history." (Guo Jun, 2004, p. 81-90)

The above analysis on similarities in literary writing between Xiao and Joyce demonstrates the affinity of the soul of the two writers. Xiao could have finished his thesis on modernist novels for his Master's degree at SOAS of London University but for the breakout of the Second World War. When, at the age of 80, he accepted the commission by Yilin Press to translate Ulysses into Chinese, it rekindled his earlier enthusiasm about Ulysses. Xiao's translation techniques of the novel will be expounded later in this dissertation, but here it suffices to point out that Xiao is a qualified translator of Joyce, whose ideas on choosing a proper author to translate echoes finely what Dillion Wentworth, the English translator, advocated four centuries ago. In Essay on Translated Verse (1685), Wentworth wrote (Lefevere, 1992, p. 43):

Then seek a Poet who your way does bend,

And choose an Author as you choose a Friend:

United by this sympathetic Bond,

You grow familiar, intimate and fond;

Your Thoughts, you Words, your Styles, your Souls agree

No longer his interpreter, but he.

\section{CONCLUSION}

As a renowned modernist novelist, Joyce is very creative in his literary writing, maneuvering freely the English language to express his deep hatred for religious hypocrisy and colonizing oppressions, as well as well-masked patriotism for his motherland. In Ulysses, the best of his three novels, Joyce employs a vast variety of stylistic experiments, making it a novel of kaleidoscopic styles. Though very hard to translate, this nationalistic epic in prose has been translated into many languages, some supervised by the author himself. The complete Chinese versions of the novel were produced by Xiao and Jin in the 1990s, 70 years later since its publication in Paris in 1922. Of the two translators, Xiao arouses our major interest because he is not only an experienced translator, but an established writer in Chinese as well, and his literary composition shares some common features with Joyce, showing a kindred spirit between the two authors.

\section{REFERENCES}


[1] Attridge, D. (1990). James Joyce. Cambridge: Cambridge University Press.

[2] Bulson, E. (2008). The Cambridge Introduction to James Joyce. Shanghai: Shanghai Foreign Language Education Press.

[3] Butler, C. (1990). Joyce, modernism, and post-modernism. In D. Attridge (ed.) James Joyce. pp. 259-282. Cambridge: Cambridge University Press.

[4] Gibson, A. (2002). Joyce's Revenge: History, Politics, and Aesthetic in Ulysses. Oxford: Oxford University Press.

[5] Gillespie, M. P. and Gillespie, P. F. (2000). Recent Criticism of James Joyce's Ulysses: An Analytical Review. Woodbridge: Camden House.

[6] Guo, Jun. (2004). James Joyce: Nightmare of History and Art of Trauma. Foreign Literature Review, 2004(3):81-90.

[7] Halliday, M. A. K. (1973). Exploration in the Functions of Language. London: Edward Arnold.

[8] Jin, Di. (2001). Shamrock and Chopsticks. Hong Kong: City University of Hong Kong Press.

[9] Lawrence, K. (1981). The Odyssey of Style in Ulysses. Princeton: Princeton University Press.

[10] Lefevere, A. (1992). Translation/History/Culture: A Source book. London and New York: Routledge.

[11] Lv, Jun. (1995). On the Two Chinese Translations of Ulysses. Shandong Foreign Language Teaching Journal, 1995 (1):35-40.

[12] Miller, M. A. (2006). Masterpieces of British Modernism. Westport: Greenwood Press.

[13] Norris, M. (1990). Finnegans Wake. in D. Attridge (ed.) James Joyce. pp. 161-184. Cambridge: Cambridge University Press.

[14] Semino, E. and Short, M. (2004). Corpus Stylistics: Speech, writing and thought presentation in a corpus of English writing. London and New York: Routledge.

[15] Wang, Yougui. (2000). Joyce in China: 1922-1999. Comparative Literature in China, 2000(2): 79-80.

[16] Xiao, Qian. (2005a). Ulysses. Nanjing: Yilin Press.

[17] Xiao, Qian. (2005b). Complete Works of Xiao Qian. Wuhan: Hubei People's Press.

Qing Wang was born in Yantai, China in 1969. She graduated from Shandong University, China, in 2010 with $\mathrm{Ph}$. D in Translation Studies.

She is currently associate professor in Department of English, Shandong Jiaotong University, Jinan, China. Her research interests include translational stylistics, literary stylistics, and corpus translation studies.

Dr. Wang is a member of China Association for the Philosophy of Language. 